\title{
Shifts in foreign trade, competitiveness and growth potential : from Baltics to "Bal-techs"?
}

Citation for published version (APA):

Lankhuizen, M. (1997). Shifts in foreign trade, competitiveness and growth potential : from Baltics to "Baltechs"? MERIT, Maastricht Economic Research Institute on Innovation and Technology. MERIT Research Memoranda No. 009 https://doi.org/10.26481/umamer.1997009

Document status and date:

Published: 01/01/1997

DOI:

10.26481/umamer.1997009

Document Version:

Publisher's PDF, also known as Version of record

\section{Please check the document version of this publication:}

- A submitted manuscript is the version of the article upon submission and before peer-review. There can be important differences between the submitted version and the official published version of record.

People interested in the research are advised to contact the author for the final version of the publication, or visit the DOI to the publisher's website.

- The final author version and the galley proof are versions of the publication after peer review.

- The final published version features the final layout of the paper including the volume, issue and page numbers.

Link to publication

\footnotetext{
General rights rights.

- You may freely distribute the URL identifying the publication in the public portal. please follow below link for the End User Agreement:

www.umlib.nl/taverne-license

Take down policy

If you believe that this document breaches copyright please contact us at:

repository@maastrichtuniversity.nl

providing details and we will investigate your claim.
}

Copyright and moral rights for the publications made accessible in the public portal are retained by the authors and/or other copyright owners and it is a condition of accessing publications that users recognise and abide by the legal requirements associated with these

- Users may download and print one copy of any publication from the public portal for the purpose of private study or research.

- You may not further distribute the material or use it for any profit-making activity or commercial gain

If the publication is distributed under the terms of Article $25 \mathrm{fa}$ of the Dutch Copyright Act, indicated by the "Taverne" license above, 


\section{Shifts in Foreign Trade, Competitiveness and Growth Potential: From Baltics to "Bal-techs"?}

\section{$1 \quad$ Introduction}

Exports are an important source of economic growth. Below we will show that countries with above average competitiveness in a given sector have a growing export share in the world market for this sector. There are several sources of competitiveness. First of all, technological progress is considered to be an important source of competitiveness: it either raises productivity (price competitiveness) or increases product quality. For our present purpose, we will concentrate on the impact of technological progress on productivity. Second, (low) wages can be a source of competitiveness. And finally, a country's competitiveness can be improved by exchange rate devaluations.

In this paper, we will first try to assess the competitiveness of exports from the Baltic States, i.e. Estonia, Latvia and Lithuania. That is, we will evaluate in what sectors the Baltics have improved their export position. Moreover, we will assess what factors account for improved export performance. We find competitiveness of the Baltics in sectors with little technologyintensity. We argue that the reason is the inferiority of production technology in the Baltics in comparison with the technology frontier. We find that, as yet, there is little indication that production technology is improving relative to the frontier, so the increases in labour productivity, which we find to account for the improved export performance, cannot be attributed to technological progress. This brings us to the second issue in this paper: one may wonder whether the Baltics have the potential to catch up with the technology frontier in the future. The prerequisites for catching up are (i) a well developed stock of human capital and (ii) an organisation of this stock of human capital that promotes the diffusion of technology throughout the economy. The Baltics fulfil the first requirement, but when it comes to the organisation of human capital, and in particular the organisation of R\&D personnel, the prospects are less promising. This implies that developing competitiveness in technology-intensive sectors might take longer than generally assumed in studies that look only at the stock of human capital. The paper is organised as follows.

First, we will formally establish that there are three sources of competitiveness: 
productivity differentials, wage differentials and exchange rates. This is done in section 2 . Then, in section 3, we analyse changes in exports from the Baltic States. The analysis is split up in two parts: if one wants to evaluate the evolution of export shares of formerly centrally planned economies, one cannot omit an analysis of the Counsil for Mutual Economic Assistance (CMEA), since it has heavily influenced contemporary trade patterns in these economies. So, first we look at trade patterns until 1991. The CMEA was dissolved in January 1991, after which substantial liberalisation and stabilisation measures have been taken. The second part of the analysis of changes in exports involves changes from 1992 onward. In section 4, we will try to assess which of the abovementioned factors (productivity differentials, wage differentials, and exchange rate devaluations) can account for recent increases in export shares of the Baltic States in international markets. Section 5 deals with the analysis of catching up, and the role of human capital in this process. We end this part of the paper by a few concluding remarks in section 6 .

\section{Theoretical Framework}

\subsection{Productivity, wages and export growth}

Differences in growth rates between countries are very much dependent on differences in trade patterns across countries. ${ }^{1}$ Assume that for every sector in a country there is but one market, the world market. The growth rate of production in sector $i$ in country $j$ is then determined by the country's growth rate of its market share $\left(X_{i j}\right)$ in sector $i$ and the growth rate of the total world market for sector $i$, i.e.,

$$
\hat{Q}_{i j}=\hat{X}_{i j}+\hat{Q}_{i}^{*}
$$

where $Q_{i}^{*}=\Sigma_{j} Q_{i j}$.

In order to obtain the growth rates of aggregate production in country $j$ and the aggregate

${ }^{1}$ The following argument is taken from Verspagen (1992). 
world market, take the summation over sectors, using sector shares as weights. Then, the growth rate differential between country $j$ and the 'world' can be expressed as,

$$
\hat{Q}_{j}-\hat{Q}^{*}=\sum_{i} \sigma_{i j} \hat{X}_{i j}+\sum_{i}\left(\sigma_{i j}-\sigma_{i}^{*}\right) \hat{Q}_{i}^{*}
$$

where $\sigma$ s denote sector shares.

The first term on the right-hand side expresses that a country with above average competitiveness grows faster than others as a result of increasing export shares. The extent to which export performance feeds through on economic growth is dependent on the share of the exporting sector in total domestic production $\left(\sigma_{i j}\right)$. The second term on the right-hand side expresses that growth differences between countries are also dependent on the extent of relative specialisation. The growth differential between country $j$ and the rest of the world is reinforced if the country is relatively specialised in a sector with a high growth potential. In the extreme case that there are no differences in competitiveness, growth differentials are solely determined by relative specialisation patterns.

In the traditional Heckscher-Ohlin trade model, relative specialisation patterns are explained by factor composition. It is assumed that all countries use the same technology in production, and only differ in terms of relative factor supplies. A country that has a relative abundance of, say, unskilled labour is said to have a comparative advantage in those products that use this factor intensively. As a result, it will be relatively specialised in the production and export of labour-intensive products.

However, we choose to omit an analysis of relative specialisation for the following reason. The assumption of equality in production technology between the Baltic States on the one hand, and, e.g., the US and OECD Europe on the other, is somewhat hard to maintain in practice: production technologies used in OECD Europe and the US are generally more advanced. In other words, there are technology gaps between the Baltic States on the one hand, and the US and OECD Europe on the other. Below we will show that technology gaps lead to differences in competitiveness. Productivity differentials and wage differentials are shown to be the main sources of competitiveness, and consequently of changes in export shares.

Assume two countries, a leader country $l$ and a follower country $f$. The rate of technological progress in the leader country is higher than in a laggard. We define technological 
progress as the improvement of production technologies. By this definition, production technology in the leader country is superior to production technology in the laggard. Letting $\pi_{i l}$ and $\pi_{i f}$ denote the growth rate of labour productivity in sector $i$ in the leading country and the following country, respectively, it follows that the rate of productivity growth is highest in the leader country. How does this affect trade? We assume that countries are engaged in a process of competition for sectoral market shares based on their respective prices. Prices are determined by unit $\operatorname{costs} C_{i j}$ plus a given mark-up, or

$$
P_{i j}=\left(1+M_{i j}\right) C_{i j}
$$$$
j=l, f
$$

Define unit costs in sector $i$ as:

$$
C_{i j}=\left(\sum_{x j} P_{x j} a_{x j}+W_{i j} a_{i j}\right)
$$

where $\Sigma_{x j} P_{x j} a_{x j}$ denote the unit cost of intermediate input and $a_{i j}=L_{i j} / Q_{i j}$ is the labour coefficient (with $L_{i j}$ denoting employment in sector $i$ in country $j$ and ${ }_{i} Q$ denoting output in sector $i$ in country $j$ ).

Through equation (4) we can see that there is a trade-off between productivity, which enhances competitiveness, and wages, which diminish competitiveness. The superiority of country $l$ 's technology over country $f$ in sector $i$ entails an absolute advantage, $\pi_{i l} / \pi_{i f}$. At the same time, country $l$ faces an absolute disadvantage vis-à-vis country $f$ in terms of its wages. This follows from the relation between wages and productivity.

Wages are supposed to track labour productivity as long as the labour market is close to full employment. However, the link between wages and productivity may be distorted by labour market imbalances. In this last assumption we follow Goodwin (1967), who assumes that varying rates of unemployment govern changes in the wage rate. Let us write wage rate dynamics in sector $i$ as $^{3}$

\footnotetext{
${ }^{2}$ the equation is taken from Landesmann and Stehrer (1996).

${ }^{3}$ Let small-case letters denote rate of change.
} 


$$
w_{i j}=\pi_{i j}-h_{j} U_{j}
$$

where $U_{j}$ is the unemployment rate in a country $f$, or $l$. It is defined as ${ }^{4}$ :

$$
U_{j}=\left(\sum_{i} Q_{i} a_{i j}-N_{j}\right) / N_{j}
$$

where $a_{i j}=L_{i j} / Q_{i j}$ is the labour coefficient (with $L_{i j}$ denoting employment in sector $i$ in country $j$ and $Q_{i j}$ denoting output in sector $i$ in country $j$ ), and $\mathrm{N}$ is the working population. ${ }^{5}$

From equation (5) we can immediately see the impact of technological progress on wages. The increase in the growth rate of labour productivity in sector $i$ has a direct positive impact on the growth of wages in that sector. This effect is somewhat dampened however by an increase in the unemployment rate, as technological progress reduces the labour input requirements. If the degree of technological asymmetry is high, the technology gap may exceed the wage differential. In this case, country l's absolute disadvantage in terms of wages is more than compensated by its superior technology and, correspondingly, higher productivity. We can express this by the following inequality:

$$
\frac{\pi_{i l}}{\pi_{i f}}>\frac{w_{i l}}{w_{i f}}
$$

The role of the wage differential is an important one in this respect, since it determines the borderline between countries' sectoral competitiveness and reversal thereof. If the wage differential had dominated over the asymmetries in technology, the less advanced country $f$ would

\footnotetext{
${ }^{4}$ See footnote no. 2 .

${ }^{5}$ The latter equation expresses that there is a relation between wages in one sector and the overall situation in a country's labour market. This is to say that institutional factors play a role in labour markets.
} 
be more competitive than the advanced country $l$, notwithstanding the latter's superior technology. If the impact of institutional factors on the labour market is large in the sense that they distort the link between sectoral wages and sectoral productivity, the importance of wages is likely to increase. Let $E_{i j}$ denote sectoral competitiveness, then we can write

$$
E_{i j}=f\left(\pi_{i l}, w_{i b}, \pi_{i}, w_{i f}\right)
$$

In other words, a country's competitiveness is determined by productivity differentials and wage differentials.

A country's competitiveness is linked to its trade performance by some mechanism of selection which is (implicitly) embodied in the diversity between countries. Competitiveness can be ranked by the superiority (inferiority) of technologies: countries whose competitiveness exceeds that of others, will be 'rewarded' by a rising world-market share, and vice versa. The selection mechanism which links a country's sectoral competitiveness to its export performance can be represented by the following replicator equation:

$$
\dot{X}_{i j}=\alpha_{i j} X_{i j}\left(E_{i j}-\bar{E}\right)
$$

where $X_{i j}$ is the export share of country $j$ in the world market for sector $I$, a dot indicates growth, and a bar indicates an average level. $E_{i j}$ is given by equation (8). The standard for selection is here defined as the average level of international competitiveness,

$$
\bar{E}=\sum_{j} E_{i j} X_{i j}
$$

It can be seen that countries whose sectoral competitiveness is above (below) average, have a growing (declining) share in the sector's world market. 


\subsection{Exchange rates and export growth}

In addition to productivity differentials and wage differentials, currency devaluations can also be considered an important source of competitiveness. We assumed that countries are engaged in a process of competition for market shares based on their respective prices. A country's prices in foreign currency is directly influenced by the exchange rate of the domestic currency $e_{w j}$,

$$
P_{w}=e_{w j} P_{i j}
$$

where $P_{i j}$ is an equivalent of equation (3).

It can easily be seen that a depreciation (or a devaluation) lowers the exchange rate $e_{w j}$, and prices in foreign currency accordingly. The country's competitiveness in world markets in increased as a result. Therefore, we can also write,

$$
E_{i j}=f\left(e_{w j}\right)
$$

We can then repeat the last part of section 2.1 in which competitiveness is linked to trade performance by the replicator equation (9). 


\section{The evolution of trade patterns}

\subsection{The CMEA}

Contemporary trade patterns in all Central and Eastern European countries and the successor states of the former Soviet Union have been influenced heavily by their past. So, if one attempts to make a proper assessment of the changes in former Socialist countries' trade with Western Europe since 1989, one has to pay explicit attention to the role of the Council for Mutual Economic Assistance (CMEA). ${ }^{6}$

Established in 1949, the CMEA was intended to serve "the purpose of co-operation to achieve the objective of balanced industrialisation" [Hillman and Schnytzer (1992), p. 521] across its members. ${ }^{7}$ In other words, the benefits of 'international' division of labour were also recognised in socialist economies. Patterns of specialisation were negotiated bilaterally. ${ }^{8}$ Trade was based on physical volumes, rather than on values. External relative prices used in CMEA trade were negotiated ex ante to ensure that trade would be balanced bilaterally, and were therefore devoid of any proper signalling function. ${ }^{9}$ Moreover, external relative prices did not feed through upon prices for domestic producers. In each CMEA country the right to conduct actual trade, once negotiations had been concluded, was given exclusively to a small number of Foreign Trade Organisations (FTOs) for respective ranges of products. As such, FTOs were the sole intermediary between domestic firms and international markets (both CMEA and non-CMEA). Trade flows were denominated in transferable rubles. ${ }^{10}$ However, FTOs and

It should be noted that the description of the CMEA below applied in full extent to the USSR only. The countries in Central Europe (notably Poland and Hungary) undertook reforms in the 1980s in order to decentralise foreign trade (Kaminski, Wang and Winters (1996)). So, the distortions in the latter countries' trade are likely to be somewhat smaller (but still substantial) than in the successor states of the former USSR.

7 The CMEA members were the USSR, Poland, the German Democratic Republic, Czechoslovakia, Hungary, Romania, Bulgaria, Mongolia, Cuba, and Vietnam. Yugoslavia was an associate member.

${ }^{8}$ The USSR supplied mostly fuels and minerals to Eastern European countries, and the Eastern European exports to the CMEA members consisted to a large extent of machinery.

${ }^{9}$ Prices reflected the importance attributed to products by governments rather than relative scarcity.

10 Within the CMEA, all bilateral accounts were cleared by the International Bank for Economic Co-operation (Schrenk (1992)) and ex post 'payments' were made to each country in transferable rubles. These transferable rubles lacked most properties of money (means of payment, store of value and, most importantly, measure of value), it was merely a unit of account. As a result, a surplus could not be used to purchase additional imports from a defecting trade partner. Nor was there a future obligation to supply on the part of a deficit country (Hillman and Schnytzer (1992)). There may have been a downward bias on the volume of trade, as countries tried 
domestic enterprises dealt with each other in domestic currency exclusively. The result is that domestic enterprises were completely isolated from international prices. Moreover, prices for traded goods in domestic currency were highly distorted as they were set so as to ensure balanced trade in domestic currency. ${ }^{11}$ So, international prices played only a very limited role - to say the least - in conveying information to enterprises in the CMEA arrangement. Consequently, patterns of specialisation within the CMEA framework did not reflect comparative advantage or relative prices.

Another significant feature of the CMEA arrangement is its creation of a duality in trade within the CMEA on the one hand, and trade with market economies on the other. Supply in socialist economies was determined by the central plan. The inputs deemed necessary to fulfil the output targets were allocated to the various industries via a system of administrative planning. Prices for producers were fixed by the government and they reflected government priorities in the sense that inputs for some industries were heavily subsidised. ${ }^{12}$ Consumer prices were not entirely fixed. However, demand was regulated through the use of taxes and subsidies. For example, prices of cars and electric appliances were heavily taxed so as to discourage demand (Lavigne 1995). By applying different pricing rules for the production sector on the one hand and the consumer on the other, producer and consumer markets were effectively separated. The socialist economy was a supply-restricted economy: whatever was supplied was determined by the central plan, eliminating every kind of consumer sovereignty. So, consumer preferences were effectively eliminated. The result of this was that producers did not have to worry about quality and product variety, not to mention innovation. 'More of the same' became the motto.

This motto dictated trade throughout the CMEA framework: the products that were traded were generally of low quality and the extent of product and process innovation was low. This distinguished trade within the CMEA framework from trade on Western markets where competitiveness in price or quality were the rules played by. Products traded within the CMEA are referred to as 'soft', as opposed to 'hard' products which are sold against hard currency on Western markets. The softness of products traded within the CMEA made such products highly

to prevent running surpluses, since this meant they were implicitly subsidising a deficit country (Schrenk (1992)).

${ }^{11}$ See Schrenk (1992) for details on what is called the principle of price of equalisation.

${ }^{12}$ Heavy industry was assigned the highest priority since this sector would produce the machinery necessary to achieve industrialisation.The overriding policy objective of the Bolsjevik revolution in 1917 in Russia was to drag the economy out of backwardness and accomplish modernisation by constructing a socialist state. Ever since then, Soviet type of socialist development has emphasised industrialisation. 
context-specific, in the sense that these products could not be (easily) redirected to world markets. ${ }^{13}$ This created a duality in trade, with low-quality trade within the CMEA on the one hand, and trade conforming to international quality standards on world markets on the other.

In summary, the CMEA has had a major impact on trade patterns in Central and Eastern Europe and the USSR by (i) centralising trade and isolating enterprises from world market prices, thereby preventing trade from being determined by comparative advantage or relative prices, and (ii) creating a duality in trade, with commodities traded within the CMEA largely unmarketable in Western markets because of their low quality.

The extent to which these features apply to the Baltic States can be illustrated by referring to data on trade in 1990 in the former USSR in Watson (1994). ${ }^{14}$ The results are shown in Tables 1 and 2. Table 1 displays the value of trade in domestic prices and an approximation of its world market value. The world market value of extrarepublic trade in hard currency is calculated as follows: per sector, the hard currency value is converted into so-called 'foreign trade rubles' by using a sector-specific, official exchange rate. ${ }^{15}$ By adding up the sectoral values, one can derive the world market value of total trade. Notwithstanding its obvious shortcomings in reflecting true world market value, this exercise does illustrates our point: there are differences between international prices and domestic prices. In other words, domestic enterprises are cut off from the former's influence.

The Baltics' commodity pattern of interrepublic and foreign trade is shown in Tables 1 and 2, respectively. Machinery, light industry products, food products and, to a lesser extent, chemicals were the main categories of trade in all three countries in 1990. In all three countries, there were large deficits in total trade in machinery. The fact that these deficits were dominated by large deficits in interrepublic trade, implies that imported technology was mainly of low quality and outdated. In the light industry, all countries ran surpluses in interrepublic trade and deficits in extrarepublic trade. In other words, the surpluses in light industry trade were generated in soft markets, whereas trade on hard markets yielded deficits. The surpluses in soft markets dominated so that overall trade in light industry was in surplus. This implies that the 'competitive

${ }^{13}$ Exceptions are products which are fairly standard such as fuels and minerals.

${ }^{14}$ Within the CMEA framework, over 90 per cent of total exports and approximately 80 per cent of total imports (own calculations based on Watson's (1994) data) in the Baltics were within the USSR. Therefore, we take interrepublic trade to be the Baltic equivalent of CMEA trade.

15 Note that even official exchange rates are highly distorted because they were determined through administrative planning rather than by market forces. That is why the world market value of trade is an approximation. 
strength' in the light industry was in low-quality products. The fact that exports in the main export categories (e.g. machinery, light industry and chemicals) were almost totally dependent on interrepublic markets (over 90 per cent of total exports in these categories was interrepublic) implies that Baltic exports were generally of low quality and capital intensive, and practically unmarketable in world markets.

When the CMEA collapsed in January 1991, followed by the disintegration of the USSR two months later, enterprises throughout the CMEA were suddenly exposed to world market prices, which in most cases meant coping with deteriorating terms of trade as prices of fuels rose and prices of machinery dropped, and were faced with the challenge of having to redirect their exports to the West. The next section analyses how the Baltic States have adjusted their trade patterns in the aftermath of the abovementioned events.

\subsection{Changes in exports after trade liberalisation}

As of 1992-93 (CEECs and the Baltics, respectively), macroeconomic stabilisation policies and foreign trade liberalisation implemented at the beginning of the transition process have taken effect. Strict monetary and interest rate policies have been implemented to bring down inflation rates, which soared after price liberalisation in 1991-92. Estonia and Lithuania adopted a currency board ${ }^{16}$ to provide an anchor for prices. Moreover, extensive currency reforms have been undertaken, with the introduction of national currencies in all three countries in the course of 1992-94. The Baltic States have virtually eliminated all export controls and state trading (Kaminski, Wang and Winters (1996)), so that firms can engage in foreign trade themselves and are exposed to foreign competition. Moreover, as a result of currency convertibility domestic producers are no longer isolated from international price signals.

Let us analyse how trade patterns in the Baltic States changed during and after these reforms. We will focus on trade with the European Union (EU) as the emerging major trade partner, as opposed to the formerly centrally planned economies, mainly the Commonwealth of Independent States (CIS). Ideally we would have liked to use export shares of the Baltics in the EU market as a measure of competitiveness, but as the statistical yearbooks of Estonia, Latvia

\footnotetext{
${ }^{16}$ Under a currency board arrangement, base money must be fully backed by foreign exchange reserves. A central bank "is bound by a money creation rule that limits growth in base money to growth in foreign exchange reserves. The extension of central bank credit to commercial banks is limited to the amount of foreign reserves in excess of those needed to provide full backing to the base money issue." [IMF (1994a), p. 20]
} 
and Lithuania do not classify trade in SITC, this has not been possible. Therefore, we use exports from the Baltic States to the EU as an indicator of competitiveness (with the exception of Latvia for which total exports are used), and compare export performance to imports. The results are shown in Tables 3-5.

Trade between Estonia and the EU has increased across the board from very low base levels in 1992. Both with respect to imports and exports the EU has become the main trading partner as of 1995. This trade has not replaced trade with the CIS, though: with the exception of exports of 'footwear, headgear, umbrellas, ...' and imports of 'miscellaneous manufactured articles', trade with the CIS on the one hand, and with the EU on the other hand has increased over 1992-95 (Statistical Yearbook of Estonia 1996). The recovery of real output during 1993, after a cumulative decline of 30 per cent in 1991-93 (IMF (1994b)), accounts to a large extent for this increase. The fastest growing export categories are (in declining order) 'wood \& articles of wood', 'mechanical \& electrical machinery', 'optical instruments \& apparatus', 'footwear, headgear, umbrellas, and 'textile \& textile articles'. However, only in 'wood \& articles of wood' Estonia has an export surplus in trade with the EU. Notwithstanding a growth rate of 8,377 per cent over 1992-95 in 'mechanical \& electrical machinery' exports, there's a substantial trade deficit in this category.

In Lithuania there appears to be trade reorientation of trade from the CIS to the EU in some categories, although the fact that figures for 1995 only cover January-September (Department of Statistics to the Government of the Republic of Lithuania, 1995-96). ${ }^{17}$ In 'footwear, headgear, umbrellas, ...', 'mechanical \& electrical machinery', 'optical instruments \& apparatus, ...' and 'miscellaneous manufactured articles' CIS is still the main export destination, but the volumes are decreasing whereas exports to the EU in these categories have increased in the period 1994-95(until September). However, imports from the EU in these four categories exceed exports by far. Export surpluses in trade with the EU are obtained in 'wood \& articles of wood', 'textiles \& textile articles', and 'base metals \& articles of base metal'.

Exports in Latvia decline between 1993 and 1995 in such categories as 'footwear, headgear, umbrellas, ...', 'transport vehicles' and 'optical instruments \& apparatus', but increase otherwise. Total exports increase in 1993-95. The strongest export growth rates are found in 'wood \& articles of wood', 'plastics \& articles thereof; rubber', and 'pulp of wood; paper \&

\footnotetext{
${ }^{17}$ From these figures it is difficult to draw conclusions about total trade volumes. The IMF (1994a) estimated output recovery and increased trade volumes from mid-1993.
} 
paperboard', but the last two categories start from low initial volumes. Main export categories, i.e. categories with export surpluses, are 'raw hides, leather, furskin $\&$ articles', 'wood $\&$ articles of wood', 'textiles \& textile articles', and 'base metals \& articles of base metal'.

It appears from these tables that the Baltics are competitive in such categories as 'wood $\&$ articles of wood', 'textiles \& textile articles' and 'base metals $\&$ articles of base metal'. These seem to be the type of products that require little adjustment when redirected from soft markets to hard markets. This pattern was to be expected to ensue after the break-up of the CMEA.

\section{Sources of Competitiveness}

\subsection{Productivity and Wage Differentials}

What role do productivity and wage differentials play in the growth of exports? Data only go as far as 1992, the year in which most stabilisation and liberalisation policies have been implemented. As it takes time for the effects of these policies to come about, no firm conclusions with respect to the medium and long run can be drawn. The data are reported in Table 6 . We have been able to find data for Latvia only. From the table it can be seen that both wages and labour productivity increase in 1990-91, and even more so between 1991 and 1992. This implies that competitiveness in terms of wages in Latvia is being eroded. The wage increase between 1990 and 1991 is lower than the increase in labour productivity in the same period, but in 1992 wage growth accelerates and in 7 out of 12 categories wage increases exceed productivity growth. Exceptions are 'wood \& articles of wood', 'pulp of wood; paper \& paperboard', 'articles of stone, plaster, cement, ...', 'base metals \& articles of base metal' and 'transport vehicles'. In these categories growth of productivity also exceeds wage growth from 1990 to 1992. It will hardly be surprising to find that productivity growth between 1990 and 1992 has been highest in these categories (growth rates of 2,322 per cent, 1,853 per cent, 2,198 per cent, 2,438 per cent, and 2,843 per cent, respectively). The high growth of labour productivity in 'wood \& articles of wood', and 'base metals \& articles of base metal' corresponds with good export performance (Table 5). Ideally, we would have liked to compare growth rates of wages and labour productivity 
in Latvia with corresponding growth rates in the EU. ${ }^{18}$ Nevertheless, the abovementioned increases in labour productivity should give a fair explanation of the increases in exports (shares) mentioned above. In other words, productivity growth is a source of competitiveness in 'wood $\&$ articles of wood', and 'base metals \& articles of base metal'.

Increases in productivity growth appear due to improved resource allocation in the short run, rather than improvements in the level of technology (dealt with in section 2.1). The level of technology in the Baltics is still far below the level in industrialised market economies. The size of the technology gap can be gauged from an analysis of 'unit values'. The unit values of exports and imports are calculated by dividing the respective dollar values by the corresponding physical weights. The UN Economic Commission for Europe describes how, by comparing the unit values of exports and imports in the same categories, one can assess the difference in technology: "[a] higher export "unit value" than that of imports for a given category may either reflect a quality advantage of exported goods over imported ones, which in turn may arise from more advanced production technology or higher skills, or it can be the result of the exported goods being technologically different from the imported ones, (...)." [UNECE (1990), p. 48] The exercise of calculating unit values has been carried out. Again due to data limitations, we have only been able to do so for Latvia. The results in Table 7 show unit value ratios, i.e. unit values of exports divided by the corresponding unit values of imports. A ratio of more (less) than one, indicates that the technology content of exports is higher (lower) than that of imports.

It can easily be seen that the level of technology in Latvia is below that of its trading partners (the majority of which are OECD-Europe countries) in most categories. Exceptions are 'products of chemical \& allied industries', 'plastics \& articles thereof; rubber', 'raw hides, leather, furskin \& articles', and 'articles of stone, plaster, cement, ...'. But in case of 'products of chemical \& allied industries' the unit value ratio is decreasing over the period 1993-1996.I. There is no sign of increasing unit value ratios in 'wood \& articles of wood', and 'base metals $\&$ articles of base metal', so the growth in labour productivity cannot be explained by catching up in terms of the level of technology. The analysis of unit values also explains why growth of labour productivity of 2,843 per cent in 'transport vehicles' has no (visible) effect on exports: the level of production technology is too low to produce high-quality transport vehicles that are

\footnotetext{
${ }^{18}$ The exercise of calculating growth rates of labour productivity and wages for the EU is currently being carried out.
} 
competitive in international markets.

The issue of technological disadvantage in the Baltics is particularly critical in high-tech sectors: these are the sectors in which technological progress is the main source of competitiveness (through rapid productivity gains), but at the same time these are the sectors in which the Baltics lag behind the most. Innovation and quality were given low priority under socialism. Raising the level of technology is dependent on the Baltics' ability to catch up in terms of the level of technology. We will turn to the analysis of the catching up potential later. First, let us analyse the role of exchange rates in export growth.

\subsection{Exchange Rates}

In section 3.2 we mentioned the fact that all three Baltic countries undertook radical currency reforms, consisting of the introduction of national currencies. In June 1992, Estonia introduced the kroon under a currency board arrangement. Rubles were converted into kroons at a rate of 10:1 ruble-to-kroon, and the kroon was fixed at EEK 8/DM. In dollars, the kroon was introduced at EEK 11.8/\$. The rate for the year 1992 was EEK 11.7/\$. The kroon depreciated in 1993 (EEK 13.2/\$) and 1994 (EEK 14.6/\$), but strengthened again in 1995 (EEK 13.7/\$) and $1996($ EEK 11.9/\$).

Latvia introduced the Latvian ruble as the only obligatory means of payment in July, 1992. The Latvian ruble was replaced by a new national currency, the lats, in October 1993. Latvian rubles were converted into lats at a 200:1 Latvian rubles-to-lats rate. The exchange rate of the lats in 1992 was lats $0.72 / \$$ and remained constant over $1993 .{ }^{19}$ It depreciated to about lats $0.57 / \$$ in 1994 , and further down to lats $0.51 / \$$ in 1995 , at which time the depreciation bottomed out and the exchange rate started to appreciate (lats $0.54 / \$$ in 1996 and lats $0.6 / \$$ in the first quarter of 1997).

In Lithuania, the Russian ruble was replaced as legal tender by the talonas in October 1992. In June 1993, the litas was introduced at a 100:1 talonas-to-litas conversion rate. In April 1994, Lithuania adopted a currency board and the litas was fixed at Llt $4 / \$$, reflecting a 2.5 per cent depreciation from the level prevailing in the weeks prior to the introduction of the currency board arrangement (IMF (1994a)). For the exchange rate developments in 1993 we quote the

\footnotetext{
${ }^{19}$ The 1992 and 1993 exchange rates have been calculated by converting the exhange rate of Latvian rubles (source IMF (1994c)) into lats by using the conversion rate of 200:1 Latvian ruble-to-lats.
} 
IMF: “(...) The exchange rate of the domestic currency, after some depreciation in the early part of the year, strengthened considerably, to Llt 3.9/\$ by 1993, almost the same as at the end of 1992.” [IMF (1994a), p. 1]

In all three countries, the exchange strengthens again after some intial depreciation. Are these exhange rate movements reflected in trade figures? Given the short period for which data have been available, it's difficult to draw robust conclusions. We cannot study changes in exports after appreciation has started. In Estonia the kroon depreciates between 1992-94. The largest increase in total exports to the EU is to be found in 1995, in other words immediately ensuing the depreciation. In Latvia, depreciation occured in 1993-95. In the same period, exports grew at 18.9 per cent and 30.48 per cent, respectively. We can say very little about the role of the exchange rate in Lithuania: we only have data on trade for 1994-95, a period in which the litas has remained fixed at Lls $4 / \$$. Based on the (admittedly, limited) data, the above seems to indicate that growing exports coincide with depreciation. This conclusion exacts caution, however.

Judging the evidence of sources of competitiveness mentioned above, we can say that the case is strongest for increases in labour productivity. Growth in labour productivity seems to provide a good explanation for the strong export performance in 'wood and articles of wood' and 'base metals \& articles of base metals' in Latvia. Strong growth in wages (in some cases exceeding growth in labour productivity) reduces the advantage that the Baltic countries have over the EU. Little can be said about the role of exchange rates due to the limited availability of data.

The increase in labour productivity is due mainly to improved resource allocation, rather than technological progress. The level of technology in the Baltics is still below that of the technological frontier. As mentioned earlier, this is of biggest consequence in the high-tech sectors. Is there any potential in Estonia, Latvia and Lithuania to catch up with the frontier and perhaps even close the technology gap and thus become competitive in these high-tech sectors? We will deal with this question in the next section. 


\section{$5 \quad$ Catching Up and Future Competitiveness}

\subsection{Prerequisites for Catching Up}

Technological progress is generated by creating and diffusing new knowledge or new combinations of existing knowledge. One of the characteristics attributed to knowledge in theory (see e.g. Romer (1990)), is that it is a non-rival good. In other words, once knowledge has been produced it can be reproduced at little or no additional cost. This implies that countries that lag behind technological leaders can capitalise on knowledge developed at the technological frontier. As a result, they are able to catch up with the leader countries relatively easy.

However, we argue that catching up is more complex. A lagging country may not be able to absorb kowledge if it does not have sufficient capacity to absorb knowledge spill-overs. Below we will argue that a lagging country needs sufficient human capital in order to catch up with the technological frontier. But more importantly, it needs to organise this human capital so as to promote communication of knowledge.

Absorbing knowledge from the technological frontier, first of all requires qualified researchers who are able to interpret information about, and understand, the new technology and recognise its value in operation. In other words, a lagging country needs a strong human capital base with the emphasis on scientific, engineering and technical skills.

Secondly, a lagging country needs to organise the co-ordination and exchange of this new knowledge between different organisations and groups of organisations throughout the economy, which requires well developed managerial skills. Technological progress involves different types of organisations such as universities, research institutes and firms. Each type of organisation generates knowledge that is to a large extent specific to the organisation. As a result, knowledge diffusion between these types of organisations is restricted. On the one hand, knowledge spillovers absorbed by universities or research institutes cannot be implemented in productive processes instantaneously; on the other hand, innovations in production techniques as a result of technology transfer, or the need for new technology because of changing consumer demands, may not find scientific back-up. It means that successful diffusion of knowledge spill-overs requires the mobilisation, co-ordination, and integration, of many different types of knowledge.

A wide diversity of types of knowledge increases the costs and risks of acquiring information. Therefore, Lundvall and Johnson (1994) argue, markets are no longer characterised by anonymous relationships between separate users and producers based on perfect knowledge. 
Communication, and in many cases even interaction, between knowledge producing organisations, and between organisations that produce new knowledge and organisations that use new knowledge, becomes vital.

The factor determining the effectiveness of communication of new knowledge is the organisation of human capital. Skills, in our case technological skills in particular, need to be organised in such a way as to promote effective communication of knowledge. To realise exchange of knowledge about new technologies at a national level, i.e. between many organisations and at different levels, e.g. between upstream and downstream firms, between universities and industries, or between research institutes (public or private) and industries, between the system of production and the financial system, and between the public and the private sector, technological skills must be allocated across the various types of organisations involved in technological progress. In this manner, researchers in, for example, universities can convey knowledge to researchers in firms who then can 'translate' and adapt this knowledge to the firm's specific context.

In summary, if the base of human capital is too low, or the organisation of human capital not effective in promoting communication, a lagging country is not likely to close the technology gap and will fall behind.

\subsection{Catching-Up Potential in the Baltics: what are the possibilities for future 'Bal-techs'?}

It is often argued that the comparative advantage of former socialist countries and the Baltic countries in particular is established by their well educated populations (Sorsa (1994)). Given these well developed stocks of human capital, an indication of which is given by data on enrollment rates in secundary and tertiary education, ${ }^{20}$ these countries should export more technologically intensive products in the longer run. However, viewed in the light of the previous analysis, having a well developed stock of human capital may not be sufficient to catch up with the technological frontier, and increase competitiveness in technology intensive sectors. Human capital, and scientists, engineers and technicians, in particular, must be organised in such a way as to promote diffusion of knowledge.

We use UNESCO data to illustrate the organisation of R\&D personnel, i.e. personnel

20 Data (UNESCO (1996)) indicate that enrollment rates in secundary education in the Baltics are comparable with Western countries, and that enrollment in tertiary education is slightly below Western countries. 
engaged in research and experimental development. R\&D personnel consists of scientists and engineers, technicians and auxiliary personnel. It can be employed in research performed in the productive sector, be it integrated or non-integrated $R \& D$, research performed in institutes of higher education, or research performed in the general service sector. The productive sector contains:

“(a) both domestic and foreign-owned industrial and trading establishments located in the country, which produce and distribute goods and services for sale, and organisations directly serving them, whatever their form of ownership, private, non-profit, or government. (...)

(b) Also included are governmental or non-governmental organisations and private non-profit institutions mainly or exclusively serving industrial or trading establishments, except those institutes, experimental stations, etc., operating under the direct control of or being associated with institutions of higher education. In socialist countries, R\&D institutes of branch ministries are to be classified in this sector." [UNESCO (1974), p. 544-545] With respect to the distinction between integrated and non-integrated R\&D, UNESCO remarks the following: "Due to the different structure of the productive sector in countries with different socio-economic systems and in order to facilitate comparisons, the R\&D effort should be measured on the following two 'levels':

(a) Integrated $R \& D$. This includes all $R \& D$ activities integrated or directly associated with other economic activities of industrial and trading establishments (...).

(b) Non-integrated $R \& D$. This includes all $R \& D$ activities not integrated in or directly associated with other economic activities, executed by such governmental or non-governmental organisations or institutes as defined in (b) above which are serving a specific two- or three digit group (ISIC) of the economy, (...) in the case of East European countries, (...) the Technical and Economic Progress Fund.” [UNESCO (1974), ibid.] The general service sector contains all activities not belonging to the productive sector or higher education. Included among other things are laboratories of national research councils and Academies of Science. The organisation of $\mathrm{R} \& \mathrm{D}$ personnel in the Baltics in comparison with countries that belong to the technological frontier is shown in Table 8.

There is a striking difference between technological leaders such as the United States, Japan, and Germany, and the Baltic countries. In the former, R\&D personnel is mainly employed in the productive sector. These countries are also the ones with the highest level of technology in production, or rapid technological progress in production. In the latter very little $R \& D$ personnel is integrated in production. It is concentrated in higher education and the general 
service sector. Research in the general service sector is dominated by the Academies of Science. There, the emphasis is mainly on theoretical, fundamental research rather than on applied research. This structure reflects the low priority given to technological progress in production in socialist economies in general (Lankhuizen (forthcoming)). The small percentage of R\&D personnel in the productive sector implies that few scientific innovations are implemented in production and explains why the level of production technology in these countries is so low. We conclude that the organisation of human capital in the Baltics does not particularly suit easy communication of new knowledge to organisations involved in production. This organisation is more suitable for scientific purposes, in which it has reportedly been succesful (World Bank (1992)).

How likely is this organisation to be changed? The organisation of human capital in processes of generating and diffusing new knowledge is determined within the context of its national system of innovation. The process of innovation takes place within the wider context of a country's structure of production. Thus, the organisation of human capital, in its turn, is determined within the context of the production structure. Production, and as a part thereof, innovation are determined by countries' culture, ideology and government policies (Johnson (1992)). According to Johnson, "modern production is an organised process, which relies heavily upon behavioural regularities." [Johnson (1992), p. 39] He refers to such behavioural regularities as institutions. Let us follow Johnson and Gregersen (1995) in distinguishing between formal and informal institutions. Informal institutions can take many forms like e.g., norms of co-operation, organisational conventions and practices. They are highly qualitative but nonetheless crucial elements in national systems of innovation, because without them communication would not be possible. Codes of communication are embedded in a larger framework of habits, norms, routines, established practices and rules, that have been shaped by a country's history, culture, and education. Formal institutions reflect culture as well as government policies, and ideologies. Institutions are formal in the sense that they have been written down. They set standards for the development and quality of new technology, its diffusion, as well as the co-operation in networks. Examples include patent laws, laws and regulation about technical service, joint venture regulations, diffusion oriented public policies.

In fact, all organisations and their behaviour are influenced by these institutions, giving them a common denominator. The production structure and the national system of innovation will also reflect a country's institutional set-up. There is a strong case of path dependence in institutional change. The rate and direction of institutional change are highly dependent upon the 
historical structure of the institutional set-up. These have developed through centuries and therefore change is likely to be slow. As the institutional set-up is highly country-specific, institutional change exhibits strong country-specific path dependence. It might be here that we find the most fundamental restriction to international learning and the international transfer of technology. Catching up by the Baltics as seen in this light might take longer than assumed in studies that only look at the amount of human capital in these countries.

\section{Conclusion}

We can conclude that the Baltics are heavily influenced by their socialist past. A past in which producers were isolated from consumer preferences and price signals, in which efficiency and quality were of little consequence, and in which innovation play a negligible role. Their production structure and export structure today reflects all this. Change is going to be slow and costly. It is going to require the transformation of the entire economy. The issue of international competitiveness, which we dealt with in this part, cannot be regarded separately from structural reform in the domestic economies, as competitiveness in international markets ultimately derives from country-specific advantages. Exploitation or creation of advantages cannot be achieved without privatisation and investments in start-up activity, a sound financial system, and other market institutions. Structural reform must create the basis for export performance, which can then sustain, or generate, additional growth. 


\section{References}

Brus, W. and Laski, K. (1989), From Marx to the Market: Socialism in search of an economic system, Clarendon Press, Oxford.

Gregory, P.R. (1990), 'The Stalinist Command Economy' in The Annals of the American Academy of Political and Social Sciences, Vol. 507, pp. 18-25.

Hillman, A.L. and Schnytzer, A. (1992), "Creating the Reform Resistant Dependent Economy: Socialist Comparative Advantage, Enterprise Incentives and the CMEA" in Hillman, A.L. and Milanovic, B. [eds], The Transition from Socialism in Eastern Europe: Domestic Restructuring and Foreign Trade, The World Bank, Washington, pp. 243-262.

IMF (1994a), Economic Reviews: Lithuania, no. 6.

IMF (1994b), Economic Reviews: Estonia, no. 7.

IMF (1994c), Economic Reviews: Latvia, no. 10.

Kaminski, B., Wang, Z.K. and Winters, L.A. (1996), Foreign Trade in the Transition: The International Environment and Domestic Policy, The World Bank.

Landesmann, M.A. and Stehrer, R. (1996), Catching Up, Wage Structures and Employment paper presented at the METEOR Conference 'Innovation, Evolution, and Technology', August 25-27 1996, Maastricht.

Lundvall, B. and Johnson, B. (1994), 'The Learning Economy' in Journal of Industry Studies, Vol. 1, No. 2, pp. 23-42.

Schrenk, M. (1992), “The CMEA System of Trade and Payments: Initial Conditions for Institutional Change" in Hillman, A.L. and Milanovic, B. [eds], The Transition from Socialism in Eastern Europe: Domestic Restructuring and Foreign Trade, The World Bank, Washington, pp. 217-242.

UNECE (1990), Economic Bulletin for Europe, vol. 42.

Sorsa, P. (1994), Regional Integration and the Baltics: which way, Policy Research Working Paper 1390, World Bank.

Verspagen, H.H.G. (1992), Uneven Growth Between Interdependent Economies: an evolutionary view on technology gaps, trade and growth, Universitaire Pers Maastricht.

Watson, R.A. (1994), 'Interrepublic trade in the former Soviet Union: structure and implications' in Post-Soviet Geography, Vol. 35, No. 7, pp. 371-408.

World Bank (1992a), Estonia: The Transition to a Market Economy, A World Bank Country Study, Washington, D.C. 
World Bank (1992b), Latvia: The Transition to a Market Economy, A World Bank Country Study, Washington, D.C.

World Bank (1992c), Lithuania: The Transition to a Market Economy, A World Bank Country Study, Washington, D.C. 


\section{Appendix}

\section{Table 1}

Interrepublic Trade, 1990 (million rubles)

\section{A. Estonia}

\begin{tabular}{|l|c|c|c|c|}
\hline & Domestic prices & & World prices & \\
\hline & export & import & export & import \\
\hline Industry: & 2689.9 & 2942.7 & 1745.8 & 2946.2 \\
\hline power & 112.2 & 12.6 & 168.3 & 18.9 \\
\hline oil \& gas & 0 & 228.7 & 0 & 516 \\
\hline coal & 0 & 2.9 & 0 & 2.7 \\
\hline other fuels & 13.3 & 0.2 & 9 & 0.1 \\
\hline $\begin{array}{l}\text { ferrous } \\
\text { metallurgy }\end{array}$ & 6 & 139.7 & 7.2 & 163.2 \\
\hline chemicals & 295.7 & 459.9 & 244.6 & 387.7 \\
\hline machinery & 541.9 & 1015.4 & 559 & 1257.5 \\
\hline wood \& paper & 127.5 & 74 & 77.8 & 50.5 \\
\hline construction & 29.2 & 46 & 27 & 41.6 \\
\hline materials & 8545.2 & 480.6 & 302.7 & 172.1 \\
\hline light industry & 632.1 & 291.2 & 294.6 & 107.4 \\
\hline food products & 70.3 & 94.1 & 43.1 & 65.7 \\
\hline other industrial & & & & \\
\hline
\end{tabular}


Table 1 (continued)

Interrepublic Trade, 1990 (million rubles)

\section{B. Latvia}

\begin{tabular}{|l|c|c|c|c|}
\hline & Domestic prices & & World prices & \\
\hline & export & import & export & import \\
\hline Industry: & 4626.9 & 4445.9 & 3549.6 & 4643.6 \\
\hline power & 87.5 & 111.1 & 131.3 & 166.7 \\
\hline oil \& gas & 5.6 & 447.4 & 12.5 & 1006.1 \\
\hline coal & 0 & 10.1 & 0 & 9.4 \\
\hline other fuels & 0 & 0.2 & 0 & 0.1 \\
\hline $\begin{array}{l}\text { ferrous } \\
\text { metallurgy }\end{array}$ & 94.9 & 346.9 & 114.8 & 414.7 \\
\hline chemicals & 646.3 & 596.2 & 533.7 & 477.9 \\
\hline machinery & 1376.4 & 1587.7 & 1565.7 & 1794.8 \\
\hline wood \& paper & 115 & 135.8 & 77.9 & 100.4 \\
\hline construction & 68.6 & 65.4 & 49.7 & 68 \\
\hline materials & 888.2 & 617.3 & 314.2 & 184.2 \\
\hline light industry & 1082 & 230.6 & 588.6 & 80.4 \\
\hline food products & 249.3 & 158.6 & 139.3 & 109.3 \\
\hline other industrial & & & & \\
\hline
\end{tabular}


Table 1 (continued)

Interrepublic Trade, 1990 (million rubles)

\section{Lithuania}

\begin{tabular}{|l|c|c|c|c|}
\hline & Domestic prices & & World prices & \\
\hline & export & import & export & import \\
\hline Industry: & 5048.5 & 5615.9 & 3972.1 & 7687.4 \\
\hline power & 199.8 & 98.8 & 299.7 & 148.2 \\
\hline oil \& gas & 232.6 & 879.1 & 518 & 2359.4 \\
\hline coal & 0 & 14.1 & 0 & 31.2 \\
\hline other fuels & 0 & 0 & 0 & 0 \\
\hline $\begin{array}{l}\text { ferrous } \\
\text { metallurgy }\end{array}$ & 21.2 & 306.1 & 19.4 & 357.3 \\
\hline chemicals & 370.2 & 735.4 & 297.7 & 610.6 \\
\hline machinery & 1832.4 & 2069.2 & 1833.4 & 2417.2 \\
\hline wood \& paper & 157.1 & 183 & 119.9 & 135.1 \\
\hline construction & 65.8 & 112.3 & 63.1 & 104.8 \\
\hline materials & 48 & 125.6 & 36.3 & 186.8 \\
\hline light industry & 1394.3 & 664 & 431.9 & 103.2 \\
\hline food products & 720.3 & 270.3 & 341.3 & 86.4 \\
\hline other industrial & 48 & & & \\
\hline
\end{tabular}

Source: Watson (1994) 
Table 2

Extrarepublic Trade, 1990 (million rubles)

\section{A. Estonia}

\begin{tabular}{|l|c|c|c|c|}
\hline & Domestic prices & & World prices & \\
\hline & export & import & export & import \\
\hline Industry: & 190.9 & 657.1 & 114.8 & 315.4 \\
\hline power & 0 & 20.3 & 0 & 30.4 \\
\hline oil \& gas & 0 & 0 & 0 & 0 \\
\hline coal & 0 & 3.5 & 0 & 5 \\
\hline other fuels & 0.4 & 0 & 0.3 & 0 \\
\hline ferrous & 10.2 & 7.8 & 15.2 & 10.5 \\
\hline metallurgy & 7.3 & 52.6 & 5.9 & 38.1 \\
\hline chemicals & 23.4 & 131.1 & 26.4 & 107.5 \\
\hline machinery & 16.6 & 5.7 & 9.5 & 3.9 \\
\hline wood \& paper & 1.2 & 4.9 & 1 & 1.6 \\
\hline construction & 4.6 & 13.9 & 3.8 & 4.8 \\
\hline materials & 42.8 & 278.4 & 16.6 & 4.1 \\
\hline light industry & 8.4 & 134 & 36.1 & \\
\hline food products & & & & \\
\hline other industrial & & & & \\
\hline
\end{tabular}


Table 2 (continued)

Extrarepublic Trade, 1990 (million rubles)

B. Latvia

\begin{tabular}{|l|c|c|c|c|}
\hline & Domestic prices & & World prices & \\
\hline & export & import & export & import \\
\hline Industry: & 223.8 & 1431.8 & 165 & 873.2 \\
\hline power & 0 & 0 & 0 & 0 \\
\hline oil \& gas & 0 & 1.4 & 0 & 1.6 \\
\hline coal & 0 & 22.9 & 0 & 32.9 \\
\hline other fuels & 0 & 0 & 0 & 0 \\
\hline $\begin{array}{l}\text { ferrous } \\
\text { metallurgy }\end{array}$ & 5 & 8.2 & 5.2 & 10.6 \\
\hline chemicals & 6.8 & 136.5 & 6.2 & 106.6 \\
\hline machinery & 98 & 391.8 & 94.2 & 311.4 \\
\hline wood \& paper & 21.5 & 19.1 & 13.1 & 12.3 \\
\hline construction & 4.1 & 6.1 & 3.5 & 2.3 \\
\hline materials & 3.5 & 32.7 & 28.5 & 107.6 \\
\hline light industry & 26.9 & 416 & 2.9 & 9.9 \\
\hline food products & 58 & 395.8 & & \\
\hline other industrial & & & & \\
\hline
\end{tabular}


Table 2 (continued)

Extrarepublic Trade, 1990 (million rubles)

C. Lithuania

\begin{tabular}{|l|c|c|c|c|}
\hline & Domestic prices & & World prices & \\
\hline & export & import & export & import \\
\hline Industry: & 407.7 & 1498.4 & 395.3 & 851 \\
\hline power & 0 & 0 & 0 & 0 \\
\hline oil \& gas & 72.7 & 0.9 & 161.3 & 1 \\
\hline coal & 0 & 0 & 0 & 0 \\
\hline other fuels & 3.2 & 0 & 2.2 & 0 \\
\hline $\begin{array}{l}\text { ferrous } \\
\text { metallurgy }\end{array}$ & 1.3 & 13.6 & 1.7 & 17.7 \\
\hline chemicals & 15.8 & 145.2 & 12.4 & 110.1 \\
\hline machinery & 174.5 & 498.6 & 147 & 400.6 \\
\hline wood \& paper & 32.7 & 12.7 & 19.8 & 7.9 \\
\hline construction & 5.5 & 14.1 & 4.7 & 8.3 \\
\hline materials & 31.6 & 492.3 & 13.7 & 121.9 \\
\hline light industry & 67.2 & 283.9 & 29.5 & 2.5 \\
\hline food products & 35.6 & & & 171.6 \\
\hline other industrial & 3 & & & \\
\hline
\end{tabular}

Source: Watson (1994) 
Table 3

Exports (\$ million) to EU, Estonia

\begin{tabular}{|l|c|c|c|c|}
\hline & 1992 & 1993 & 1994 & 1995 \\
\hline $\begin{array}{l}\text { products of chemical } \\
\text { \& allied industries }\end{array}$ & 6.56 & 8.95 & 15.08 & 26.67 \\
\hline $\begin{array}{l}\text { plastics \& articles } \\
\text { thereof; rubber }\end{array}$ & 0.80 & 1.71 & 1.69 & 17.15 \\
\hline $\begin{array}{l}\text { raw hides, leather, } \\
\text { furskin \& articles }\end{array}$ & 3.17 & 2.83 & 4.20 & 11.58 \\
\hline $\begin{array}{l}\text { wood \& articles of } \\
\text { wood }\end{array}$ & 1.75 & 13.08 & 40.35 & 151.9 \\
\hline $\begin{array}{l}\text { pulp of wood; paper } \\
\text { \& paperboard }\end{array}$ & 0.59 & 0.35 & 0.81 & 7.10 \\
\hline textiles \& textile art. & 5.68 & 22.55 & 31.85 & 149.4 \\
\hline $\begin{array}{l}\text { footwear, headgear, } \\
\text { umbrellas, ... }\end{array}$ & 0.64 & 2.35 & 5.52 & 17.04 \\
\hline $\begin{array}{l}\text { articles of stone, } \\
\text { plaster, cement, ... }\end{array}$ & 1.87 & 2.17 & 1.92 & 8.18 \\
\hline $\begin{array}{l}\text { precious \& semi- } \\
\text { precious stones, .. }\end{array}$ & 0.48 & 4.0 & 0.92 & 3.65 \\
\hline $\begin{array}{l}\text { base, metals \& } \\
\text { articles of base metal }\end{array}$ & 4.62 & 21.92 & 26.5 & 78.47 \\
\hline $\begin{array}{l}\text { mechanical \& } \\
\text { electrical machinery }\end{array}$ & 3.86 & 7.81 & 15.98 & 62.13 \\
\hline transport vehicles & 0.14 & 1.06 & 0.73 & 7.84 \\
\hline $\begin{array}{l}\text { optical instruments \& } \\
\text { apparatus, ... }\end{array}$ & 0.11 & 147.5 \\
\hline arms \& ammunition \\
\hline miscellaneous & 0.0 & 0.01 & 0.0 & 0.01 \\
\hline
\end{tabular}


Table 3 (continued)

Imports (\$ million) from EU, Estonia

\begin{tabular}{|l|l|l|l|l|}
\hline & 1992 & 1993 & 1994 & 1995 \\
\hline $\begin{array}{l}\text { products of chemical } \\
\text { \& allied industries }\end{array}$ & 4.47 & 15.02 & 32.79 & 102.7 \\
\hline $\begin{array}{l}\text { plastics \& articles } \\
\text { thereof; rubber }\end{array}$ & 1.62 & 6.74 & 14.62 & 75.15 \\
\hline $\begin{array}{l}\text { raw hides, leather, } \\
\text { furskin \& articles }\end{array}$ & 0.33 & 1.02 & 2.40 & 11.93 \\
\hline $\begin{array}{l}\text { wood \& articles of } \\
\text { wood }\end{array}$ & 0.06 & 0.64 & 0.99 & 15.67 \\
\hline $\begin{array}{l}\text { pulp of wood; paper } \\
\text { \& paperboard }\end{array}$ & 0.86 & 3.27 & 5.02 & 56.69 \\
\hline textiles \& textile art. & 5.91 & 17.67 & 31.55 & 151.6 \\
\hline $\begin{array}{l}\text { footwear, headgear, } \\
\text { umbrellas, ... }\end{array}$ & 0.51 & 2.14 & 7.53 & 23.09 \\
\hline $\begin{array}{l}\text { articles of stone, } \\
\text { plaster, cement, ... }\end{array}$ & 0.64 & 1.78 & 5.10 & 32.28 \\
\hline $\begin{array}{l}\text { precious \& semi- } \\
\text { precious stones, .. }\end{array}$ & 0.14 & 0.17 & 0.27 & 4.07 \\
\hline $\begin{array}{l}\text { base, metals \& } \\
\text { articles of base metal }\end{array}$ & 1.50 & 5.64 & 12.41 & 97.08 \\
\hline $\begin{array}{l}\text { mechanical \& } \\
\text { electrical machinery }\end{array}$ & 18.11 & 38.74 & 75.82 & 376.0 \\
\hline transport vehicles & 12.40 & 34.72 & 38.69 & 92.75 \\
\hline $\begin{array}{l}\text { optical instruments \& } \\
\text { apparatus, ... }\end{array}$ & 1.28 & 7.63 & 13.65 & 36.08 \\
\hline arms \& ammunition \\
\hline miscellaneous & 0.05 & 0.51 & 0.49 & 0.49 \\
\hline
\end{tabular}

Source: Statistical Yearbook of Estonia 


\section{Table 4}

\section{Exports (\$ million) to EU, Lithuania}

\begin{tabular}{|c|c|c|}
\hline & 1994 & $\begin{array}{l}1995^{2} \\
1\end{array}$ \\
\hline $\begin{array}{l}\text { products of chemical } \\
\& \text { allied industries }\end{array}$ & 96.25 & 94.23 \\
\hline $\begin{array}{l}\text { plastics \& articles } \\
\text { thereof; rubber }\end{array}$ & 10.85 & 24.09 \\
\hline $\begin{array}{l}\text { raw hides, leather, } \\
\text { furskin \& articles }\end{array}$ & 14.85 & 15.68 \\
\hline $\begin{array}{l}\text { wood \& articles of } \\
\text { wood }\end{array}$ & 41.53 & 79.68 \\
\hline $\begin{array}{l}\text { pulp of wood; paper } \\
\& \text { paperboard }\end{array}$ & 3.98 & 2.88 \\
\hline textiles \& textile art. & 98.92 & 152.8 \\
\hline $\begin{array}{l}\text { footwear, headgear, } \\
\text { umbrellas, ... }\end{array}$ & 5.07 & 5.42 \\
\hline $\begin{array}{l}\text { articles of stone, } \\
\text { plaster, cement, ... }\end{array}$ & 2.18 & 4.44 \\
\hline $\begin{array}{l}\text { precious \& semi- } \\
\text { precious stones, ... }\end{array}$ & 7.57 & 0.94 \\
\hline $\begin{array}{l}\text { base, metals \& } \\
\text { articles of base metal }\end{array}$ & 51.12 & 89.06 \\
\hline $\begin{array}{l}\text { mechanical \& } \\
\text { electrical machinery }\end{array}$ & 23.60 & 48.02 \\
\hline transport vehicles & 15.40 & 9.89 \\
\hline $\begin{array}{l}\text { optical instruments \& } \\
\text { apparatus, ... }\end{array}$ & 1.95 & 2.0 \\
\hline arms \& ammunition & 0.02 & 0.04 \\
\hline $\begin{array}{l}\text { miscellaneous } \\
\text { manufact. articles }\end{array}$ & 14.27 & 14.55 \\
\hline
\end{tabular}

\footnotetext{
211995 January-September
} 
Table 4 (continued)

Imports (\$ million) from EU, Lithuania

\begin{tabular}{|c|c|c|}
\hline & 1994 & $1995^{2}$ \\
\hline $\begin{array}{l}\text { products of chemical } \\
\& \text { allied industries }\end{array}$ & 52.28 & 62.16 \\
\hline $\begin{array}{l}\text { plastics \& articles } \\
\text { thereof; rubber }\end{array}$ & 31.02 & 49.27 \\
\hline $\begin{array}{l}\text { raw hides, leather, } \\
\text { furskin } \& \text { articles }\end{array}$ & 3.88 & 5.36 \\
\hline $\begin{array}{l}\text { wood \& articles of } \\
\text { wood }\end{array}$ & 3.95 & 8.18 \\
\hline $\begin{array}{l}\text { pulp of wood; paper } \\
\& \text { paperboard }\end{array}$ & 16.61 & 28.14 \\
\hline textiles \& textile art. & 82.88 & 113.8 \\
\hline $\begin{array}{l}\text { footwear, headgear, } \\
\text { umbrellas, ... }\end{array}$ & 5.88 & 3.80 \\
\hline $\begin{array}{l}\text { articles of stone, } \\
\text { plaster, cement, ... }\end{array}$ & 7.19 & 12.62 \\
\hline $\begin{array}{l}\text { precious \& semi- } \\
\text { precious stones, ... }\end{array}$ & 0.55 & 1.33 \\
\hline $\begin{array}{l}\text { base, metals \& } \\
\text { articles of base metal }\end{array}$ & 25.85 & 43.03 \\
\hline $\begin{array}{l}\text { mechanical \& } \\
\text { electrical machinery }\end{array}$ & 191.5 & 183.5 \\
\hline transport vehicles & 60.40 & 82.09 \\
\hline $\begin{array}{l}\text { optical instruments \& } \\
\text { apparatus, ... }\end{array}$ & 19.58 & 27.63 \\
\hline arms \& ammunition & 0.60 & 0.46 \\
\hline $\begin{array}{l}\text { miscellaneous } \\
\text { manufact. articles }\end{array}$ & 15.58 & 18.38 \\
\hline
\end{tabular}

Source: Lithuania's Statistical Yearbook

$$
221995 \text { January-September }
$$


Table 5

Total exports (\$ million), Latvia

\begin{tabular}{|c|c|c|c|c|}
\hline & 1993 & 1994 & 1995 & $\begin{array}{c}1996 . \\
\text { I }\end{array}$ \\
\hline $\begin{array}{l}\text { products of chemical } \\
\& \text { allied industries }\end{array}$ & 69.93 & 72.71 & 83.41 & 21.74 \\
\hline $\begin{array}{l}\text { plastics \& articles } \\
\text { thereof; rubber }\end{array}$ & 6.07 & 8.85 & 13.49 & 2.51 \\
\hline $\begin{array}{l}\text { raw hides, leather, } \\
\text { furskin \& articles }\end{array}$ & 15.49 & 17.88 & 21.57 & 5.75 \\
\hline $\begin{array}{l}\text { wood } \& \text { articles of } \\
\text { wood }\end{array}$ & 88.94 & 201.8 & 344.6 & 71.28 \\
\hline $\begin{array}{l}\text { pulp of wood; paper } \\
\& \text { paperboard }\end{array}$ & 8.03 & 8.41 & 15.19 & 6.18 \\
\hline textiles \& textile art. & 127.5 & 130.9 & 182.6 & 54.9 \\
\hline $\begin{array}{l}\text { footwear, headgear, } \\
\text { umbrellas, ... }\end{array}$ & 22.43 & 17.3 & 8.97 & 2.72 \\
\hline $\begin{array}{l}\text { articles of stone, } \\
\text { plaster, cement, ... }\end{array}$ & 13.78 & 12.97 & 26 & 6.76 \\
\hline $\begin{array}{l}\text { precious \& semi- } \\
\text { precious stones, ... }\end{array}$ & 7.65 & 2.11 & 2.41 & 0.33 \\
\hline $\begin{array}{l}\text { base, metals \& } \\
\text { articles of base metal }\end{array}$ & 85.85 & 100.2 & 103.3 & 17.46 \\
\hline $\begin{array}{l}\text { mechanical \& } \\
\text { electrical machinery }\end{array}$ & 72.44 & 91.66 & 113.7 & 29.5 \\
\hline transport vehicles & 125.3 & 98.4 & 83.19 & 17.18 \\
\hline $\begin{array}{l}\text { optical instruments \& } \\
\text { apparatus, ... }\end{array}$ & 6.19 & 6.05 & 5.79 & 1.06 \\
\hline arms \& ammunition & 0.23 & 0.18 & 0.12 & 0.02 \\
\hline $\begin{array}{l}\text { miscellaneous } \\
\text { manufact. articles }\end{array}$ & 34.77 & 44.6 & 57.81 & 13.15 \\
\hline
\end{tabular}


Table 5 (continued)

Total imports (\$ million), Latvia

\begin{tabular}{|l|c|c|c|c|}
\hline & 1993 & 1994 & 1995 & $\begin{array}{c}1996 . \\
\text { I }\end{array}$ \\
\hline $\begin{array}{l}\text { products of chemical } \\
\text { \& allied industries }\end{array}$ & 69.14 & 126.3 & 198.2 & 56.72 \\
\hline $\begin{array}{l}\text { plastics \& articles } \\
\text { thereof; rubber }\end{array}$ & 17.24 & 36.03 & 65.96 & 16.71 \\
\hline $\begin{array}{l}\text { raw hides, leather, } \\
\text { furskin \& articles }\end{array}$ & 3.63 & 4.59 & 6.16 & 1.77 \\
\hline $\begin{array}{l}\text { wood \& articles of } \\
\text { wood }\end{array}$ & 2.79 & 6 & 14.14 & 2.68 \\
\hline $\begin{array}{l}\text { pulp of wood; paper } \\
\text { \& paperboard }\end{array}$ & 13.29 & 36.94 & 77.28 & 22.55 \\
\hline $\begin{array}{l}\text { textiles \& textile art. } \\
\text { footwear, headgear, }\end{array}$ & 44.55 & 73.37 & 139.5 & 36.95 \\
\hline $\begin{array}{l}\text { umbrellas, ... } \\
\text { articles of stone, } \\
\text { plaster, cement, .. }\end{array}$ & 10.55 & 10.71 & 12.72 & 2.81 \\
\hline $\begin{array}{l}\text { precious \& semi- } \\
\text { precious stones, .. }\end{array}$ & 0.94 & 0.95 & 2.03 & 0.37 \\
\hline $\begin{array}{l}\text { base, metals \& } \\
\text { articles of base metal }\end{array}$ & 42.7 & 62.05 & 112.6 & 25.76 \\
\hline $\begin{array}{l}\text { mechanical \& } \\
\text { electrical machinery }\end{array}$ & 95.98 & 200.8 & 305.5 & 77.7 \\
\hline transport vehicles & 88.06 & 83.42 & 142.8 & 32.17 \\
\hline $\begin{array}{l}\text { optical instruments \& } \\
\text { apparatus, ... }\end{array}$ & 10.11 & 30.14 & 35.47 & 10.84 \\
\hline arms \& ammunition & 0.95 & 1.63 & 2.04 & 0.19 \\
\hline miscellaneous & 12.51 & 22.16 & 41.21 & 10.05 \\
\hline
\end{tabular}

Source: Central Statistical Bureau of Latvia 


\section{Table 6}

A.

\section{Dollar Wages per Employee in Latvia}

\begin{tabular}{|c|c|c|c|}
\hline & 1990 & 1991 & 1992 \\
\hline $\begin{array}{l}\text { products of chemical \& allied } \\
\text { industries }\end{array}$ & 28 & 43 & 511 \\
\hline plastics \& articles thereof; rubber & 26 & 42 & 321 \\
\hline $\begin{array}{l}\text { raw hides, leather, furskin \& } \\
\text { articles }\end{array}$ & 28 & 53 & 429 \\
\hline wood $\&$ articles of wood & 26 & 49 & 351 \\
\hline $\begin{array}{l}\text { pulp of wood; paper \& } \\
\text { paperboard }\end{array}$ & 23 & 50 & 338 \\
\hline textiles \& textile art. & 23 & 50 & 359 \\
\hline $\begin{array}{l}\text { footwear, headgear, umbrellas, } \\
\ldots^{23}\end{array}$ & 30 & 39 & 429 \\
\hline $\begin{array}{l}\text { articles of stone, plaster, cement, } \\
\ldots\end{array}$ & 27 & 53 & 357 \\
\hline $\begin{array}{l}\text { base, metals } \& \text { articles of base } \\
\text { metal }\end{array}$ & 27 & 50 & 397 \\
\hline $\begin{array}{l}\text { mechanical \& electrical } \\
\text { machinery }\end{array}$ & 26 & 48 & 314 \\
\hline transport vehicles & 28 & 54 & 442 \\
\hline $\begin{array}{l}\text { optical instruments \& apparatus, } \\
\text {... }\end{array}$ & 26 & 44 & 260 \\
\hline
\end{tabular}

Source: own calculations based on UNIDO data.

Note: in order to derive dollar amounts we have used the 1992 exchange rate of 0.72 lats $\$$. This is calculated by converting the 1992 Latvian ruble-to-dollar exchange rate into lats, using a conversion rate of 200:1 Latvian Rubleto-lats (IMF (1994c)).

${ }^{23}$ UNIDO-data covering only footwear have been used. 
Table 6 (continued)

B.

Labour Productivity (output per employee), in dollars, in Latvia

\begin{tabular}{|c|c|c|c|}
\hline & 1990 & 1991 & 1992 \\
\hline $\begin{array}{l}\text { products of chemical \& allied } \\
\text { industries }\end{array}$ & 408 & 910 & 7029 \\
\hline plastics \& articles thereof; rubber & 175 & 437 & 1992 \\
\hline $\begin{array}{l}\text { raw hides, leather, furskin \& } \\
\text { articles }\end{array}$ & 226 & 999 & 3528 \\
\hline wood \& articles of wood & 106 & 265 & 2567 \\
\hline $\begin{array}{l}\text { pulp of wood; paper \& } \\
\text { paperboard }\end{array}$ & 214 & 602 & 4179 \\
\hline textiles \& textile art. & 220 & 603 & 2802 \\
\hline $\begin{array}{l}\text { footwear, headgear, umbrellas, } \\
\ldots{ }^{24}\end{array}$ & 140 & 791 & 3026 \\
\hline $\begin{array}{l}\text { articles of stone, plaster, cement, } \\
\ldots\end{array}$ & 111 & 299 & 2551 \\
\hline $\begin{array}{l}\text { base, metals \& articles of base } \\
\text { metal }\end{array}$ & 154 & 309 & 3909 \\
\hline $\begin{array}{l}\text { mechanical \& electrical } \\
\text { machinery }\end{array}$ & 140 & 279 & 1750 \\
\hline transport vehicles & 129 & 330 & 3797 \\
\hline $\begin{array}{l}\text { optical instruments \& apparatus, } \\
\ldots\end{array}$ & 97 & 139 & 766 \\
\hline
\end{tabular}

Source: own calculations based on UNIDO data.

Note: in order to derive dollar amounts we have used the 1992 exchange rate of 0.72 lats $\$$. This is calculated by converting the 1992 Latvian ruble-to-dollar exchange rate into lats, using a conversion rate of 200:1 Latvian Rubleto-lats (IMF (1994c)).

${ }^{24}$ UNIDO-data covering only footwear have been used. 
Table 7

Unit Value Ratios, Latvia

\begin{tabular}{|c|c|c|c|c|}
\hline $\begin{array}{l}\text { Harmonised } \\
\text { commodity } \\
\text { description }\end{array}$ & $\begin{array}{l}\text { unit value ratio } \\
\text { (export/import) }\end{array}$ & & & \\
\hline & 1993 & 1994 & 1995 & 1996.I \\
\hline $\begin{array}{l}\text { products of chemical \& } \\
\text { allied ind }\end{array}$ & 21.4 & 2.48 & 1.92 & 1.66 \\
\hline $\begin{array}{l}\text { plastics \& articles } \\
\text { thereof; rubber }\end{array}$ & 1.44 & 1 & 0.88 & 1.07 \\
\hline $\begin{array}{l}\text { raw hides, leather, } \\
\text { furskin \& artcls }\end{array}$ & 1.44 & 1.82 & 1.57 & 1.64 \\
\hline $\begin{array}{l}\text { wood \& articles of } \\
\text { wood }\end{array}$ & 0.41 & 0.23 & 0.27 & 0.28 \\
\hline $\begin{array}{l}\text { pulp of wood; paper \& } \\
\text { paperboard }\end{array}$ & 0.97 & 0.64 & 0.44 & 0.64 \\
\hline $\begin{array}{l}\text { textiles \& textile } \\
\text { articles }\end{array}$ & 1.1 & 0.84 & 0.85 & 1.05 \\
\hline $\begin{array}{l}\text { footwear, headgear, } \\
\text { umbrellas ... }\end{array}$ & 0.5 & 0.5 & 0.4 & 0.35 \\
\hline $\begin{array}{l}\text { articles of stone, } \\
\text { plaster, cement, .. }\end{array}$ & 0.88 & 1.17 & 1.67 & 1.45 \\
\hline $\begin{array}{l}\text { precious \& } \\
\text { semiprecious stones, ... }\end{array}$ & 0.32 & 0.99 & 0.33 & 0.88 \\
\hline $\begin{array}{l}\text { base metals } \& \text { articles } \\
\text { of base metal }\end{array}$ & 1.62 & 0.75 & 0.41 & 0.42 \\
\hline $\begin{array}{l}\text { mechanical \& electrical } \\
\text { machinery }\end{array}$ & 0.48 & 0.46 & 0.49 & 0.38 \\
\hline transport vehicles & 0.87 & 0.6 & 0.79 & 0.68 \\
\hline $\begin{array}{l}\text { optical instruments \& } \\
\text { apparatus, ... }\end{array}$ & 0.56 & 0.6 & 0.27 & 0.6 \\
\hline arms \& ammunition & 0.18 & 0.3 & 1.48 & 0.89 \\
\hline $\begin{array}{l}\text { miscellaneous manuf. } \\
\text { articles }\end{array}$ & 0.37 & 0.42 & 0.33 & 0.63 \\
\hline
\end{tabular}

Source: own calculations based on data from the Central Statistical Bureau of Latvia. 
Table 8

The Organisation of R\&D Personnel in Percentages

\begin{tabular}{|c|c|c|c|c|c|}
\hline Country ${ }^{25}$ & $\begin{array}{l}\text { Category of } \\
\text { personnel }\end{array}$ & $\begin{array}{l}\text { Productive } \\
\text { sector }\end{array}$ & & $\begin{array}{l}\text { Higher } \\
\text { education }\end{array}$ & $\begin{array}{l}\text { General } \\
\text { service }\end{array}$ \\
\hline & & $\begin{array}{l}\text { Integrated } \\
R \& D\end{array}$ & $\begin{array}{l}\text { Non- } \\
\text { integrated } \\
\text { R\&D }\end{array}$ & & \\
\hline $\begin{array}{l}\text { United States } \\
\text { (1993) }\end{array}$ & $\begin{array}{l}\text { scientists and } \\
\text { engineers } \\
\text { technicians } \\
\text { auxiliary } \\
\text { personnel }\end{array}$ & 79 & & 13 & 06 \\
\hline Japan (1992) & $\begin{array}{l}\text { scientists and } \\
\text { engineers } \\
\text { technicians } \\
\text { auxiliary } \\
\text { personnel }\end{array}$ & $\begin{array}{l}61 \\
79 \\
51\end{array}$ & & $\begin{array}{l}32 \\
11 \\
28\end{array}$ & $\begin{array}{l}07 \\
10 \\
\\
21\end{array}$ \\
\hline $\begin{array}{l}\text { Germany } \\
\text { (1991) }\end{array}$ & $\begin{array}{l}\text { scientists and } \\
\text { engineers } \\
\text { technicians } \\
\text { auxiliary } \\
\text { personnel }\end{array}$ & $\begin{array}{l}59 \\
67 \\
64\end{array}$ & & $\begin{array}{l}26 \\
14 \\
16\end{array}$ & $\begin{array}{l}16 \\
19\end{array}$ \\
\hline
\end{tabular}

${ }^{25}$ The numbers in brackets are the registration years. 


\begin{tabular}{|l|l|l|l|l|l|}
\hline $\begin{array}{l}\text { Estonia } \\
\text { (1994) }\end{array}$ & $\begin{array}{l}\text { scientists and } \\
\text { engineers } \\
\text { technicians }\end{array}$ & & & 60 & 40 \\
auxiliary & personnel & & & & 76 \\
\hline Latvia (1994) & $\begin{array}{l}\text { scientists and } \\
\text { engineers }\end{array}$ & 13 & & 61 & 39 \\
\hline & technicians & 08 & & 51 & 41 \\
& auxiliary & & & 20 & 51 \\
\hline
\end{tabular}

Source: UNESCO (1996). 